\title{
Matematik Dersinde Takım Destekli Bireyselleştirme Tekniğinin Kullanılmasına Yönelik Veli Görüşlerinin İncelenmesi ${ }^{1}$
}

\author{
Dr. Osman AKTAN* \\ Milli Eğitim Bakanlığı, Ankara / Türkiye, \\ karakteregitimi@gmail.com, ORCID: 0000-0001-6583-3765 \\ Prof. Dr. Yusuf BUDAK \\ Gazi Üniversitesi, Eğitim Fakültesi, Eğitim Bilimleri Bölümü, Ankara / Türkiye, \\ ysfbudak@gmail.com, ORCID: 0000-0001-9625-204X
}

\section{$\ddot{O} z$}

$\mathrm{Bu}$ araştırmanın amacı, ilkokul öğretim kademesinde matematik dersi öğretiminde işbirliğine dayalı öğrenme yöntemi takım destekli bireyselleştirme tekniği kullanımına yönelik veli görüşlerini belirlemektir. Nitel yaklaşımın benimsendiği araştırmada, veri toplama aracı olarak görüşme tekniği kullanılmıştır. Araştırmada, ilkokul 4. sınıf "Matematik Öğretim Programı", "Uzunlukları Ölçme, Eşit Parçalara Bölme” ünitesinde yer alan kazanımlar doğrultusunda, takım destekli bireyselleştirme tekniğine dayalı olarak hazırlanan altı haftalık (otuz saat) matematik dersi öğretim planları, 3 ayrı sınıfta 6 hafta uygulanmıştır. Uygulama başlamadan önce, uygulamanın içeriği ve süreç hakkında veliler bilgilendirilmiştir. Öğretim uygulaması bittikten sonra uygulamaya yönelik görüşlerin alınması amacıyla, altı öğrenci velisi ile görüşme yapılmıştır.

\footnotetext{
${ }^{1} \mathrm{Bu}$ makale birinci yazarın, ikinci yazar danışmanlığında hazırladığı doktora tezinden üretilmiştir.

* Sorumlu Yazar. Tel: +903805260185

Makale Tarih Bilgisi. Gönderim: 04.04.2020, Kabûl: 22.08.2020, Erken Görünüm: 02.04.2021, Basım: Aralık, 2021

(C) 2021. Kalem Eğitim ve Sağlık Hizmetleri Vakfı. Bütün Hakları Saklıdır. ISSN: 2146-5606, e-ISSN: 2687-6574.
} 
Veli görüşleri, araştırmacı tarafından hazırlanan ön uygulama ile geçerlik ve güvenirlik formu ile toplanmıştır. Verilerin analizinde içerik analizi yöntemi kullanılmıştır. Katılımcı görüşlerinden elde edilen veriler, doğrudan alıntılarla desteklenmiştir. Araştırmada elde edilen sonuçlara göre; velilerin genel olarak takım destekli bireyselleştirme tekniğine yönelik matematik dersi öğretim uygulamalarını yararlı buldukları, tekniğin gerek normal gelişim gösteren öğrenciler gerekse öğrenme güçlüğü olan kaynaştırma öğrencilerinin matematik dersine yönelik ilgilerini arttırdığı, öğrencilere dersi sevdirdiği, öğrencilerin motivasyonunu arttırdığı, işlenen dersleri anlaşılır ve eğlenceli bulduklarına yönelik sonuçlar elde edilmiştir.

Anahtar Kelimeler: Matematik dersi; İşbirliğine dayalı öğrenme yöntemi; Takım destekli bireyselleştirme tekniği; Kaynaştırma eğitimi; Özel öğrenme güçlüğü.

\title{
Investigation of Parents' Opinions about Using Team Assisted Individualization Technique in Mathematics Course
}

\begin{abstract}
The aim of this study is to determine the parental views about the use of team assisted individualization technique in mathematics teaching. The qualitative research approach was adopted, and the data collection technique interview method was used. In the research, sixs-week (thirty hours) math lesson teaching plans prepared based on team-assisted individualization technique were applied for six weeks in three different classes in line with the learning outcomes in the fourth grade Mathematics Curriculum $4^{\text {th }}$ grade "Measuring Lengths, Dividing into Equal Parts" unit. Parents were informed about the content of the application and the process before the application started. After the teaching practices were finished, six students' parents were interviewed. Parents' opinions were collected through an interview form prepared by the researcher. Content analysis method was used for data analysis. The data obtained from the participant opinions were supported by direct quotations. According to the results obtained in the research; it is aimed that parents generally find mathematics teaching practices for team-assisted individualization technique useful; the technique increases their interest in mathematics lesson for both students with normal development and learning difficulties, they love the lesson for students, increase the motivation of the students, find the lessons understood and entertaining. Keywords: Mathematics Course; Cooperative learning Method; Team-
\end{abstract}


assisted individualization technique; Family involvement; Inclusion education; Specific learning disability.

\section{Extended Summary}

\section{Introduction}

The results of the research on the application of team-assisted individualization technique showed that the technique had positive effects on the students who had learning disabilities, enabled them to progress in line with their abilities and capacities, and reduced the effects of learning disabilities in mathematics lessons, and provided the social acceptance of students with learning disabilities (Ellala and Alslaq, 2017; Madden and Slavin, 1983; Slavin, 1985; Tilaar, 2014). Today, parents care more about school success in relation to the education of children. As a requirement of this idea, parents take more responsibility for their children's participation in learning activities at school and at home (Aktaş-Arnas, 2013). The responsibilities that families take lead to a strong communication between families and the school (Cömert and Güleç, 2004). In Turkey in primary school teaching mathematics to students in mainstream education and normal development teams that have supported efforts to use personalization techniques, studies for students with normal development are mostly quantitative (Aslan, 2016; Erkoç and Artut, 2016; Gelici, 2011; Gelici and Bilgin, 2011; Gelici and Bilgin, 2012; Gülsar, 2014; Koç, 2015; Tarım and Akdeniz, 2008; Y1ldırım, 2011), it can be said that there is no study evaluating the parents' views to ensure family participation in the use of the technique.

\section{Purpose}

Evaluation of the effects of the use of team-assisted individualization technique on students' academic achievement, attitude towards the course, social acceptance and permanence level of knowledge based on parents' views in mathematics teaching, to be a resource for the use of this technique in teaching mathematics to students with normal development and inclusive education the research supports family participation and in addition, the absence of a study evaluating parents' views on the use of the technique to ensure family involvement makes the research important. The aim of this research is to determine the opinions of the parents of students regarding the use of team-assisted individualization technique in their teaching in fourth grade mathematics course. 


\section{Method}

In the research in which qualitative approach was adopted, interview technique was used as data collection method. The study group of the research consists of a total of 6 parents of students, three of whom are learning difficulties in the classes where the team-assisted individualization technique is applied, including the parent of the mainstreaming student. In the research, interview form was used as a data collection tool. During the preparation of the interview form, the opinions of different language experts (education, special education, measurement) and a language expert were consulted to ensure the validity and reliability of the interview form. In the mathematics lesson, the application for team-assisted individualization technique was planned and applied between April 24, 2017 and June 2, 2017, in three separate classes for six weeks, five hours per week. After the application was completed, interviews were conducted to determine the opinions of the parents of the students regarding the use of team-assisted individualization technique in teaching. Parent opinions obtained in the study were analyzed by content analysis method.

\section{Results}

As a result of analyzing interviews with parents, three themes were reached. These themes are; evaluation of the team-assisted individualization technique, reflections of the team-assisted individualization technique and implementation of the team-assisted individualization technique. When the parents' views about the evaluation of team-assisted individualization technique were examined, it was determined that the students liked the teaching activities of the team-assisted individualization technique, mathematics courses were nice and fun, and team studies were generally evaluated positively. When the parents' views on the theme of team-assisted individualization technique reflected on the students are examined, the students learn math subjects better, their interest in the lesson increases, the lessons are based on the reward, the students are happy and motivated, they find the math lesson easy thanks to the teaching practices, their class friendships develop and they are the first in the classroom. It was determined that they sat with different students for the first time. On the theme of the application of team-assisted individualization technique, findings were obtained that students' interest in school increased during the application, they felt sad when they did not receive awards, they formed teams with students they did not like in the classroom and that some students in the teams did not fulfill their responsibilities. 


\section{Discussion}

According to the results obtained in the research, parents found the application of team-assisted individualization technique generally beneficial, the activities for the application of the technique attracted the attention of the students, the technique made the students love the mathematics lesson, the students' interest and motivation towards the lesson positively affected the students' success in the lesson and developed a positive attitude towards the lesson. It was determined that they had opinions about being effective. In the study, in which the parents "views about the academic failure of primary school students were examined (Akbaba-Altun, 2009), the reasons for the students' failure were not to attract the students' attention, the group studies were not included and the teachers' monotonous processing of the lessons. In another study conducted by Ayaydın and Katılmış (2017), parents stated that teachers do not include different teaching methods in the lessons. Based on the findings of the research, it can be said that the teaching practices of teamassisted individualization technique is a teaching technique that responds to the expectations of the parents regarding the teaching of the lessons.

\section{Conclusion}

According to the results of the research, it was determined that the opinions of both students with normal development and parents of students with learning disabilities were positive for the use of team-assisted individualization technique in teaching mathematics lessons, and the technique also favorably supported the parent's participation. Based on the results of the research, more emphasis can be given on team-assisted individualization technique applications, which also have a teaching content that supports inclusive education practices, as it is also suitable for individual teaching in teaching mathematics and teaching other courses.

\section{Giriş}

Günümüzde eğitim sistemlerinin yapılandırılmasında bireysel farklılıklar önemli yer tutmaya başlamaktadır. Bireysel farklılıkların dikkate alındığı eğitimde, bireylerin eğitsel, sosyal ve bireysel gereksinimlerine uygun koşulların oluşturulması gerekmektedir. Özel eğitim de bireysel farklılıklar üzerinde yapılandırılan bir eğitim disiplinidir.

Özel eğitim, çoğunluktan farklı ve özel gereksinimi olan bireylere sunulan, bireyleri yetenekleri alanında en üst düzeyde geliştirmeyi amaçlayan, 
bireylerin yetersizliğinin engele dönüşmesini önleyen, özel gereksinimli bireyin kendi ihtiyaçlarına cevap verebilmesini sağlayan, uzman personel, özel olarak hazırlanan eğitim programları ve çeşitli destek hizmetleri ile verilen eğitimdir (Bryant, Smith ve Bryant, 2008). Özel eğitim yoluyla, özel gereksinimli bireylerin topluma uyumlarını kolaylaştıracak, bağımsız ve üretken bireyler olarak yaşamalarını sürdürmelerini destekleyecek beceriler edinmeleri amaçlanmaktadır (Cavkaytar, 2013). Özel eğitime muhtaç bireylerin de yaşıtları gibi öğrenmede sınırlılıkları yoktur ve eşit eğitim hakkına sahiptirler (Bruffy, 2012). Milli Eğitim Bakanlığı (MEB) Özel Eğitim Hizmetleri Yönetmeliğine (2014) göre; özel gereksinimli bireyler, işitme yetersizliği olan, üstün yetenekli, görme yetersizliği olan, bedensel yetersizliği olan, dil ve konuşma güçlüğü olan, özel öğrenme güçlüğü olan, otizm ile dikkat eksikliği ve hiperaktivite bozukluğu olan bireyler şeklinde sinıflandırılmaktadır. Milli Eğitim Bakanlığı'na bağlı örgün eğitim kurumlarında öğrenim gören toplam özel gereksinimli öğrenci sayıs1 398.815'tir. Bu oran, örgün eğitim kurumlarındaki öğrenci sayısının yaklaşık olarak \%2.2'sini oluşturmaktadır. Özel gereksinimli öğrencilerin \%14'ü özel eğitim sınıflarında, \%12'si özel eğitim okullarında, \%74'ü ise kaynaştırma öğrencisi olarak genel eğitim sınıflarında eğitimlerine devam etmektedirler (MEB, 2019, s.40). Özel gereksinimli bireyler içinde özel öğrenme güçlüğü olan öğrencilerin sayıs1 \%3'tür (Melekoğlu, 2017).

Özel öğrenme öğrenme güçlüğü, bireysel olarak uygulanan standart testler sonucunda, kişinin yaşı, ölçülen zekâ düzeyi ve aldığı eğitim göz önüne dikkate alınarak yazma, konuşma, okuma, akıl yürütme veya sayısal becerilerin kazanılmasında belirgin güçlük olarak tanımlanan heterojen bir bozukluktur (American Psychological Association [APA], 1994; Gillberg ve Soderstorm, 2003). Çocuğun yaşadığı öğrenme problemleri akademik başarısını, okuma, sayısal ya da yazma becerisi gerektiren günlük etkinliklerini olumsuz yönde etkilemektedir (APA, 1994). Özel öğrenme güçlüğü yaygın olarak, okuma bozukluğu (disleksi), yazılı anlatım bozukluğu (disgrafi) ve matematik bozukluğu (diskalkuli) olmak üzere üç alt başlıkta incelenmektedir (Köroğlu, 2013). Özel öğrenme güçlüğü tanılı öğrenciler, kaynaştırma eğitimi uygulamaları doğrultusunda akranları ile aynı sınıfta öğrenim görmektedirler (MEB, 2017).

Günümüzde özel eğitime gereksinim duyan çocukların eğitimlerinde uzmanlık bilgisi ve kişiye uygun bireysel öğretimin önemli olduğu görüşü de 
ağırlık kazanmasına rağmen, özel gereksinimli çocukların normal çocuklardan tamamen ayrıştırılması yerine akranlarıyla beraber düzenli bir eğitim ortamında eğitim almaları daha fazla kabul görmeye başlamıştır (Aral, 2011; Pijl, Meijer ve Hegarty, 1997). Kaynaştırma olarak adlandırılan bu uygulama, herhangi bir nedenle yetersizlikten etkilenen ve özel gereksinimleri olan bireylere ilave destek eğitim hizmetleri de sunularak, bireyin normal gelişim gösteren akranlarıyla birlikte eğitim almalarını kapsamaktadır (De Boer, Pijl ve Minnaert, 2010; Osborne ve DiMattia, 1994; Rafferty, Boettcher ve Griffin, 2001). Kaynaştırma eğitiminde başarı, koordineli bir çalışmayı gerektirir. Kaynaştırma eğitiminin paydaşları olan okul idaresi, rehberlik servisi, öğretmen, normal gelişim gösteren öğrenci velileri ile kaynaştırma öğrenci velisinin etkin bir iş birliği içinde olması gerekir.

Kaynaştırma eğitimin sürecinin sağlıklı ve başarılı bir şekilde yürütülmesinde ailenin katkısı büyüktür. Özel gereksinimli bireyin ailesinden alınan destek ve ailenin eğitim sürecine aktif katılımıyla, birey birçok beceriyi daha çabuk öğrenmekte; öğrendikleri becerilerin pekiştirilmesi, sürekliliğinin sağlanması aile katılımıyla daha kısa sürede gerçekleşmektedir (Allen ve Cowdery, 2015; Hirano ve Rowe, 2016). Aileler çocuklarının gözlemleri sonucu akranlarından farklı gelişim gösterdiklerini tespit edebilirler ancak ailelerin sorunu görmezden gelmesi, bu konuda yanlış bilgi kaynaklarının olması ya da nereden destek alacağını bilmemesi öğrenciye destek sürecinin gecikmesine yol açmaktadır (Kançeşme, 2015). Bu desteklerden biri de, öğrencinin eğitiminde çocuk merkezli bazı öğretim düzenlemelerinin yapılmasıdır.

Özel öğrenme güçlüğü olan öğrencilerin eğitimine başlamadan yapılacak öğretimsel düzenlemeler, öğretimin hedefine ulaşmasında etkili sonuçlar alınmasını sağlayabilir. Bu düzenlemeler özetle, öğrencinin oturduğu fiziksel ortamın sade ve dikkat çekici unsurlardan arınması, öğrencinin sevdiği akranı ile aynı sırayı paylaşması, günlük rutinlerin belirlenmesi ve bunlara uyma ile ilgili kurallar listesi oluşturulması, öğrenciye yönelik öğretim materyallerinde, içerikte ve değerlendirmede uyarlamalar yapılması, öğrencide zayıf kalan becerilerin geliştirilmesine yönelik beceri öğretimi yapılması, ders içeriklerinin görsel, işitsel, teknolojik ve somut materyallerle desteklenmesi, belli aralıklarla öğrenci performansının değerlendirilmesi, derse katılımın sağlanması ve pekiştirilmesi, yönergelerin açık, net ve anlaşılır olması, bireysel etkinlikler 
hazırlanması, grup çalışmalarına yer verilmesi, öğrencinin akranlarına tanıtılması ve akran desteği sağlanması olarak sayılabilir (Aktan, 2018; Aktan ve Budak, 2017; Fuchs ve Fuchs, 1998; Parker, 2006).

İşbirliğine dayalı öğrenme yöntemi, bireysel ve grup öğretimini içermesi, içeriğinde akran öğrenmeyi de sağladığ için özel öğrenme güçlüğü olan öğrencilerin öğretiminde alternatif bir öğrenme yöntemi olabilir. Eğitimde son yıllarda sıkça kullanılmaya başlanan işbirliğine dayalı öğrenme; öğrencilerin birbirlerinin öğrenmelerine yardımcı olma, sosyal etkileşimin olumlu etkilerinden en yüksek düzeyde yararlanma (Güvenç ve Açıkgöz, 2007; Hossain ve Tarmizi, 2011), öğrencilerin bilgi ve becerilerini birbileriyle paylaşma (Cooper ve Mueck, 1990; Ural, 2007), birlikte çalışma, problem çözme ve sosyal becerilerin gelişimini sağlama (Şimşek, Doymuş ve Bayrakçeken, 2004), gibi konularda konularında öğrencilere fayda sağlayan bir öğrenme yöntemidir. İ̧̧birliğine dayalı öğrenme, özellikle farklı gereksinimleri olan öğrencilerin bulunduğu sınıflarda, öğrencilerin akademik başarılarının yanında, aynı zamanda onların arkadaşlık ilişkilerini de geliştirme, başarı için sorumluluk alma, birbirlerinin başarılarını takdir etme ve grup etkinliklerine katılma, öğrencilere zihinsel, duyuşsal ve psikomotor davranışları kazandırma bakımından da etkili bir öğrenme yöntemidir (Friend ve Bursuck, 2014; Salend, 2008; Yeşilyurt, 2010).

İşbirliğine dayalı öğrenme yöntemi içerisinde birlikte öğrenme, iş birliği, takım-oyun-turnuva, grup araştırması, birlikte soralım-birlikte öğrenelim, birleştirilmiş işbirlikli okuma ve kompozisyon, öğrenci takımları-başarı bölümleri, akademik çelişki ve birleştirme gibi birçok teknik yer almaktadır. Bunlardan biri de takım destekli bireyselleştirme teniğidir (Yeşilyurt, 2019). Bu teknik eğitimde sık kullanılan bir öğrenme tekniğidir. Takım destekli bireyselleştirme tekniği genellikle matematik öğretiminde kullanılan işbirlikli öğrenme tekniğidir. Matematik dersinde bireysel öğrenmeyi daha etkili kılmayı amaçlayan ve bu amaçla geliştirilen bir tekniktir (Açıkgöz, 2007; Slavin, Madden ve Leavey, 1984). Slavin (1985), iş birliğine dayalı öğrenme tekniklerinin, öğrenme güçlüğü bulunan kaynaştırma öğrencileri üzerinde olumlu etkisi olduğunu belirtmektedir. Takım destekli bireyselleştirme tekniğinin uygulanması; takımların oluşturulması, öğretmen anlatımı, çalışma yaprakları, izleme testleri ve konu sınavlarının hazırlanması, grupların başarılarının değerlendirilmesine yönelik başarı sertifikalarının hazırlanması gibi basamaklardan oluşmaktadır (Kusumayanti, 2014). 
Takım destekli bireyselleştirme tekniği özel gereksinimli kaynaştırma öğrencilerine başarı deneyimini yaşayabilmeleri için olanaklar sunar. Fakat uygulama öncesinde özel gereksinimli kaynaştırma öğrencilere grup çalışmalarında gerekli olan akademik ve sosyal beceriler hakkında, normal ögrencilere ise grup üyelerini nasıl yönlendirecekleri konusunda süreç başında ve ortasında bilgi verilmelidir (Lewis ve Doorlag, 2011). Tekniğin uygulanmasında heterojen gruplar bir üst, iki orta ve bir kaynaştırma öğrencisi olacak şekilde tasarlanabilir (Haager ve Klinger, 2005). Tekniğin basit, ucuz olması, başka bir öğretmenin yardımını gerektirmiyor olması, öğrencileri işbirlikçi, eşit statülü gruplarda çalıştırarak, sınıfta farklı gereksinimli öğrenciler arasında olumlu tutumların geliştirmelerini sağlaması nedeniyle öğretimde tercih edilmektedir (Açıkgöz, 2007). Tekniğin öğrencilere matematik ders başarısı kazandırma açısından öğretmen merkezli düz anlatıma dayalı öğrenme yöntemlerine göre daha etkili olduğu ile ilgili birçok araştırma yapılmıştır (Aslan, 2016; Erkoç ve Artut, 2016; Gelici, 2011; Gelici ve Bilgin, 2011; Gelici ve Bilgin, 2012; Gülsar, 2014; Koç, 2015; Tarım ve Akdeniz, 2008; Yıldırım, 2011). Ayrıca öğrencilerde matematik dersine karşı olumlu tutum geliştirme açısından da (Gelici, 2011; Gelici ve Bilgin, 2011; Yıldırım, 2011) etkili bir öğrenme tekniği olduğu belirlenmiştir.

\section{Çalışmanın Önemi}

Takım destekli bireyselleştirme tekniğinin uygulanmasına yönelik araştırma sonuçları, tekniğin normal gelişim gösteren öğrencilerin yanı sıraözel öğrenme güçlüğü bulunan kaynaştırma öğrencileri üzerinde de olumlu etkiler bıraktığ1, öğrencilerin yetenekleri ve kapasiteleri doğrultusunda ilerlemelerini sağladığı, özellikle matematik dersinde öğrenme güçlüğünün etkilerini azalttığı ve öğrencilerin sosyal kabullerini sağlamada etkili olduğunu ortaya koymaktadır (Ellala ve Alslaq, 2017; Madden ve Slavin, 1983; Tilaar, 2014). Türkiye'de ilkokulda matematik öğretiminde takım destekli bireyselleştirme tekniği kullanımına yönelik kaynaştırma eğitimi öğrencileri ile normal gelişim gösteren öğrencilerinin birlikte ele alındığı bir çalışmanın olmadığı, normal gelişim gösteren öğrencilere yönelik çalışmaların ise daha çok nicel temelli olduğu (Aslan, 2016; Erkoç ve Artut, 2016; Gelici, 2011; Gelici ve Bilgin, 2011; Gelici ve Bilgin, 2012; Gülsar, 2014; Koç, 2015; Tarım ve Akdeniz, 2008; Yıldırım, 2011) görülmektedir. Tekniğin her iki ögrenci grubuna birlikte uygulanması ile ilgili, aile katılımını sağlamaya yönelik veli görüşlerinin değerlendirildiği bir çalışmanın olmadığı tespit edildi. 
Günümüzde aileler çocukların eğitimine ilişkin olarak okul başarısını önemsemektedirler. Aileler bu düşüncenin gereği olarak, çocuklarının okuldaki ve evdeki öğrenme aktivitelerine katılım konusunda daha fazla sorumluluk almaktadırlar (Aktaş-Arnas, 2013). Ailerin aldıkları sorumluluklar, aile katılımını pekiştirir ve aileler ile okul arasında güçlü bir iletişimin oluşmasına zemin hazırlar (Cömert ve Güleç, 2004). Aile katılımının öğrencilerinin akademik başarılarını arttırdığı (Hayakawa, Englund, Warner-Richter ve Reynolds, 2013; Topor, Keane, Shelton ve Calkins, 2010), özellikle özel gereksimli öğrencilerin okula ilgisini arttırdığı (Miksic, 2015), okul ile aile arasında işbirliği sağlayarak çocukların eğitim sürecini geliştirdiği (Waanders, Mendez ve Downer, 2007), öğrencilerin davranış problemlerinin azalmasında etkili olduğu (Kratochwill, McDonald, Levin, Scalia ve Coover, 2009), kaynaştırma eğitiminin başarıya ulaşmasına katkı sağladığ (Sucuoğlu ve Kargın, 2014), araştırma sonuçları ile ortaya konulmuştur.

Matematik gibi öğretilmesinde ve kavratılmasında güçlük çekilen bir dersin öğrenilmesi için geleneksel yöntemlerin yeterli olmadığı ve öğrenmede gerekli kalıcılığı sağlayamadığı bilinmektedir (Çelebi, 2006). Chinn (2012) ve Eshun (2004)'e göre, matematik dersine ilişkin olumlu tutumlara sahip öğrenciler matematiği sevebilir ve daha iyisini yapmak için gayret gösterebilirler. $\mathrm{Bu}$ çabanın sonunda başarı duygusunu yaşama olasılıkları artabilir. Bu başarı duygusu, olumlu tutumlarının daha kalıcı olmasını sağlar. Takım destekli bireyselleştirme tekniği özellikleri ve uygulama ilkeleri açısından öğrencilerin matematik ders başarılarını artırma ve derse karşı olumlu tutum geliştirmelerine katkı sağlayabilir.

Öğrenme ortamları, öğrenme ve öğretme süreçlerinin oluştuğu yerlerdir. Öğrencilere yönelik etkili öğrenme ortamları, öğretimde öğrencinin aktif katılıma dayanan zengin içerikli öğrenme etkinlikleri ile yapılandırılan öğretim teknikleri ile oluşturulabilir. Takım destekli bireyselleştirme tekniğinin özellikleri ve uygulama ilkeleri açısından gerek normal gelişim gösteren öğrencilere gerekse özel gereksinimli öğrencilere matematik ders başarısı sağlamada kaynak olabilir. Tekniğin öğrenci merkezli olması, etkinlik tabanlı olması, öğrencilerin akademik ve sosyal gelişimlerini sağlaması gibi özelliklere sahip olması nedeniyle aile katılımını desteklemesi, ayrıca tekniği kullanımının öğrenciler üzerindeki etkilerinin veli görüşlerine göre değerlendirildiği bir çalışmanın olmaması da araştırmayı önemli kılmaktadır. 


\section{Araştırmanın Amacı}

$\mathrm{Bu}$ araştırmada 4. sınıf matematik dersinde takım destekli bireyselleştirme tekniği kullanımının öğrenciler üzerindeki etkilerinin veli görüşlerine dayalı olarak değerlendirilmesi amaçlanmaktadır. $\mathrm{Bu}$ amaç doğrultusunda aşağıdaki alt amaçlara cevap aranmıştır:

1. Takım destekli bireyselleştirme öğrenme tekniğinin değerlendirilmesine yönelik veli görüşleri nelerdir?

2. Takım destekli bireyselleştirme öğrenme tekniğinin öğrencilere yansımaları ile veli görüşleri nelerdir?

3. Takım destekli bireyselleştirme öğrenme tekniğinin uygulanmasına yönelik veli görüşleri nelerdir?

\section{Yöntem}

\section{Araştırma Modeli}

Takım destekli bireyselleştirme tekniği kullanımının öğrenciler üzerindeki etkilerinin veli görüşlerine dayalı olarak değerlendirildiği araştırmada nitel durum desenlerinden iç içe geçmiş tek durum çalışması deseni kullanılmıştır. Durum çalışması, ele alınan olay, durum, birey, ortam veya süreçlerin ayrıntılı biçimde araştırılmasını, araştırmada ele alınan "durumu" etkileyen faktörlerin bütüncül bir bakış açısıyla incelenmesi, ele alınan duruma ilişkin etkilerini ortaya koyan bir nitel araştırma desenidir (Merriam, 2013; Yin, 2011). İç içe geçmiş tek durum çalışması ise, tek bir durumu ayrıntılı betimlemek amaciyla, durumu oluşturan birden fazla alt durum ve boyutların derinlemesine incelenmesidir (Yin, 2012). Bu araştırmada takım destekli bireyselleştirme tekniği kullanımının öğrenciler üzerindeki etkileri tek bir durum olarak ele alınmış, tekniğin etkilerine yönelik normal gelişim gösteren öğrenciler ile öğrenme güçlüğü olan kaynaştırma öğrenci veli görüşleri de alt durumlar olarak ele alınmıştır. Araştırma tek durum içinde birden fazla analiz birimi içermesi nedeniyle, iç içe geçmiş tek durum çalışması olarak tasarlanmıştır.

\section{Çalışma Grubu}

Araştırmanın çalışma grubu, 2016-2017 eğitim-öğretim y1lında, Düzce ilinde yer alan üç ilkokulda takım destekli bireyselleştirme tekniğinin uygulandığı sınıflarda öğrenim gören üçü normal gelişim gösteren üçü de kaynaştırma öğrencisi olmak üzere toplam altı öğrenci velisinden oluşmaktadır. Çalışma grubu amaçlı örneklem kapsamında kolay ulaşılabilir durum örnekleme yoluyla belirlenmiştir. Bu teknikte araştırmacı, kendisine yakın ve ulaşılması kolay olan örnekleme durumlarını seçmektedir (Yıldırım ve Şimşek, 2013). 
Çalışma grubu, araştırmaya gönüllü olarak katılan ve kolay ulaşılabilir öğrenci velilerinde oluşmuştur. Öğrenci velileri, uygulama başlamadan önce, uygulama sırasında ve uygulama sonunda öğretim süreci hakkında bilgilendirilmiştir. Görüşme yapılan veliler, gerek uygulama hakkında yapılan bilgilendirmeler gerekse çocuklarının sınıf öğretmenleri ve çocukları ile olan etkileşimleri sonucu takım destekli bireyselleştirme tekniği uygulamaları hakkında bilgisi olan kişilerdir.

\section{Veri Toplama Aracı}

$\mathrm{Bu}$ araştırmada; veri toplama aracı olarak yarı yapılandırılmış görüşme formu hazırlanmıştır. Yarı yapılandırılmış görüşmeler hem sabit seçenekli cevaplamayı hem de ilgili alanda derinlemesine gidebilmeyi birleştirir (Büyüköztürk, Çokluk-Bökeoğlu ve Köklü, 2008). Görüşmeyi yapacak kişi araştırmanın amacına uygun olarak önceden hazırladığı soruları sorabileceği gibi daha derinlemesine bilgi almak için ilave sorular da sorma hakkına sahiptir (Yıldırım ve Şimşek, 2013). Bir ölçme aracının kapsam ve görünüş geçerliği uzman görüşleriyle değerlendirilebilir (Büyüköztürk, 2017). Görüşme formunun hazırlanması sürecinde, görüşme formunun kapsam geçerliliği ve güvenirliğini sağlama adına, farklı alan uzmanları (eğitim bilimleri, özel eğitim, ölçme ve değerlendirme) ile bir dil uzmanının görüşlerine başvurulmuştur. Uzman görüşleri doğrultusunda görüşme soruları üzerinde gerekli düzeltmeler yapılarak, görüşme formuna son şekli verilmiştir. Görüşme formunda "Takım destekli bireyselleştirme öğrenme tekniğinin değerlendirilmesine yönelik görüşleriniz nelerdir?", "Takım destekli bireyselleştirme öğrenme tekniğinin öğrencilere yansımaları ile ilgili görüşleriniz nelerdir?", "Takım destekli bireyselleştirme öğrenme tekniğinin uygulanmasina yönelik görüşleriniz nelerdir?" gibi üç temel soru ve temel sorulara ilişkin 9 sonda soru olmak üzere 12 soru yer almaktadir.

\section{Uygulama Süreci ve İşlem}

Matematik dersinde takım destekli bireyselleştirme tekniği kullanıma yönelik uygulama, 24 Nisan 2017-02 Haziran 2017 tarihleri arasında, 3 ayrı sınıfta 6 hafta olacak şekilde yapılmıştır. Dersler ilkokul 4. sınıf Matematik Öğretim Programı 4. sınıf "Uzunlukları Ölçme, Eşit Parçalara Bölme" ünitesinde yer alan kazanımlar doğrultusunda, takım destekli bireyselleştirme tekniğine dayalı olarak hazırlanan 6 haftalık (30 saat) ders planları, konu ve kazanım dağılımları dikkate alınarak araştırmacı tarafından işlenmiş̧ir. Araştırma farklı okullarda yer alan üç sınıfta yürütülmüştür. Araştırma sınıfları, 
öğrencilerin dördüncü sınıf olması, sınıflarda öğrenme güçlüğü tanılı kaynaştırma öğrencisi olması, sınıflardaki normal gelişim gösteren öğrenciler ile öğrenme güçlüğü olan kaynaştırma öğrencilerinin ders başarıları açısından benzer özelliklere sahip olması, okul idareleri, öğretmenler ve velilerin uygulamaya izin vermesi, matematik tutum ölçeği ve sosyal kabul ölçeği puanlarının karşılaştırılması gibi kriterler sonucunda belirlenmiştir. Araştırma sınıflarında, 3'ü özel öğrenme güçlüğü olan kaynaştırma öğrencisi olmak üzere, toplam 73 öğrenci yer almıştır. Uygulama yapılan her üç sınıfın velileri ile etkin bir iletişim sağlanarak, süreç içerisinde uygulama başlamadan önce, uygulama sırasında ve uygulama bittikten sonra veliler bilgilendirilmişlerdir. Öğretim uygulaması tamamlandıktan sonra matematik dersinde takım destekli bireyselleştirme tekniğinin kullanımına ilişkin veli görüşlerini belirlemek amacıyla görüşmeler yapılmıştır. Görüşmeler, 02 Haziran 2017-15 Haziran 2017 tarihlerinde yapılmıştır. Katılımcıların onayları doğrultusunda görüşmeler kayıt altına alınmıştır. Araştırmada etik kurallar doğrultusunda, araştırmanın uygulamasına yönelik olarak Düzce İl Milli Eğitim Müdürlüğü Bilimsel Araştırmalar Komisyonu'ndan 09/05/2017 tarih ve E.6595441 say1lı onay ile uygulama izni alınmıştır.

\section{Verilerin Analizi}

Araştırmada veli görüşme formları içerik analiz yoluyla analiz edilerek tema ve alt temalar oluşturulmuştur. Temaların oluşturulmasında, araştırmanın alt amaçları esas alınmıştır. Kodlama yapılırken, tema ve alt temalar düzenlenirken ham verilere sadık kalınmıştır. Bu amaçla veli görüşlerinden doğrudan alıntılar kullanılarak, veriler betimlenmiştir. Kodlamalar, tema ve alt temaların oluşturulmasında araştırmacılar dışında, nitel araştırma alanında deneyimli üç öğretim üyesinin de görüşleri alınarak kodlamalar karşılaştırılmış, tema ve alt temalara son hali verilmiştir. İçerik analiz ile elde edilen verilerin güvenirliğinin sağlanması için, Miles ve Huberman'ın (2015) "Görüş Birliği/(Görüş Birliği+Görüş Ayrıllı̆ı)x100” formülü kullanılmıştır. Kodlamalara ilişkin uzman görüşleri arasındaki güvenirlik oran1 \%89 olarak tespit edilmiştir. Görüşme yapılan normal gelişim gösteren öğrenci velileri V1, V2, V3, öğrenme güçlüğü olan kaynaştırma öğrenci velileri ise VK1, VK2, VK3 şeklinde kodlanmıştır. 


\section{Bulgular}

Görüşmeler sonucu elde edilen bulgular, aşağıda temalar halinde sunulmuştur. Verilerin analizi sonucu matematik dersinde uygulanan takım destekli bireyselleştirme tekniğine yönelik veli görüşleri üç tema altında toplanmıştır. Aşağıda Tablo 1'de takım destekli bireyselleştirme tekniğinin değerlendirilmesi teması ve alt temaları ile ilgili veli görüşleri verilmiştir.

Tablo 1. Takım Destekli Bireyselleştirme Tekniğinin Değerlendirilmesi Teması ve Alt Temaları ile İlgili Veli Görüşleri

\begin{tabular}{|c|c|c|c|}
\hline 1.Tema & Alt tema & Görüşler & Frekans \\
\hline \multirow{4}{*}{$\begin{array}{l}\text { Takım Destekli } \\
\text { Bireyselleştirme } \\
\text { Tekniğinin } \\
\text { Değerlendirilmesi }\end{array}$} & \multirow{4}{*}{$\begin{array}{l}\text { Tekniğe } \\
\text { bakış }\end{array}$} & Derste yapılan etkinlikleri sevme & $2(\mathrm{VK} 1, \mathrm{~V} 3)$ \\
\hline & & $\begin{array}{l}\text { Matematik derslerinin güzel geçti- } \\
\text { ğini düşünme }\end{array}$ & 1 (VK2) \\
\hline & & $\begin{array}{l}\text { Okulda matematik derslerinde eğ- } \\
\text { lendiklerini söyleme }\end{array}$ & 1 (V4) \\
\hline & & $\begin{array}{l}\text { Takım çalışmalarının çok güzel ol- } \\
\text { duğunu söyleme }\end{array}$ & $1(\mathrm{~V} 1)$ \\
\hline
\end{tabular}

Takım destekli bireyselleştirme tekniğinin değerlendirilmesi teması ile ilgili veli görüşlerinin tekniğe bakış olmak üzere tek alt temada toplandığı görülmektedir. Veli görüşleri doğrultusunda tekniğe bakış alt temasında; derste yapılan etkinlikleri sevme ( $\mathrm{f}=2)$, matematik derslerinin güzel geçtiğini düşünme ( $f=1)$, okulda matematik derslerinde eğlendiklerini söyleme ( $\mathrm{f}=1)$ öne çıkan görüşlerdir. Aşağıda velilerin takım destekli bireyselleştirme tekniğinin genel değerlendirilmesi teması ve tekniğe bakış alt teması ile ilgili veli görüşleri doğrudan alıntılarla verilmiştir.

"Oğlum okuldan eve gelince yeni bir matematik öğretmeni geldiğini, derste çok güzel etkinlikler yaptıklarını mutlulukla anlattı... Kart vermisssiniz evde bile taktı. Ilk defa okuldaki matematik dersinden bu denli bahsetmeye başladi..." (VK1)

"Derste çok eğlendik dedi..." (V4)

“... Matematik dersimiz çok güzel geçti, çok güzel takım çalışması yaptık dedi. Gayet mutluydu..." (VK2)

Velilerin takım destekli bireyselleştirme tekniğinin değerlendirilmesi temasına yönelik görüşleri incelendiğinde, velisi bulundukları öğrencilerin derste yapılan etkinlikleri çok sevdikleri, matematik derslerinin güzel geçtiğini söyledikleri, öğrencilerin matematik derslerinde eğlendikleri, takım çalışmalarının öğrenciler tarafından beğenildiğine yönelik görüş ifade ettikleri belirlenmiştir. Aşağıda Tablo 2'de takım destekli bireyselleştirme tekniğinin 
yansımaları teması ve alt temaları ile ilgili veli görüşleri verilmiştir.

Tablo 2. Takım Destekli Bireyselleştirme Tekniğinin Yansımaları Teması ve Alt Temaları ile İlgili Veli Görüşleri

\begin{tabular}{|c|c|c|c|}
\hline 2.Tema & Alt Tema & Görüşler & Frekans \\
\hline \multirow{9}{*}{ 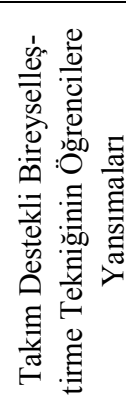 } & $\begin{array}{l}\text { Akademik } \\
\text { Başarı }\end{array}$ & Konuları daha iyi öğrenme & $2(\mathrm{VK} 3, \mathrm{~V} 4)$ \\
\hline & & Matematik dersine yönelik ilgisinin artması & $3(\mathrm{VK} 3, \mathrm{~V} 1, \mathrm{~V} 3)$ \\
\hline & & Belge aldığı için mutlu olması & $3(\mathrm{VK} 1, \mathrm{~V} 2, \mathrm{~V} 3)$ \\
\hline & Olumlu & Matematik dersini sevmesi & $2(\mathrm{~V} 2, \mathrm{~V} 1)$ \\
\hline & Tutum & Derse karşı motive olması & $2(\mathrm{~V} 1, \mathrm{~V} 3)$ \\
\hline & & Matematiğin çok kolay olduğunu söylemesi & $2(\mathrm{VK} 3)$ \\
\hline & & Yaka kartını çok sevmesi, evde de takması & $1(\mathrm{VK} 1)$ \\
\hline & Sosyal & Arkadaşlık ilişkilerinde gelişme & $1(\mathrm{VK} 1)$ \\
\hline & Kabul & İlk defa farklı öğrencilerle oturma & $1(\mathrm{~V} 1)$ \\
\hline
\end{tabular}

Takım destekli bireyselleştirme tekniğinin yansımaları teması ile ilgili veli görüşlerinin akademik başarı, olumlu tutum ve sosyal kabul olmak üzere üç alt temada toplandığı görülmektedir. Akademik başarı alt temasında; matematikte konuları daha iyi öğrenme $(\mathrm{f}=2)$ görüşü ifade edilmiştir. Olumlu tutum alt temasında; matematik dersine yönelik ilgisinin artması $(\mathrm{f}=3)$, belge aldığı için çok mutlu olması $(\mathrm{f}=3)$, matematik dersini sevmesi $(\mathrm{f}=2)$, derse karşı motive olması $(\mathrm{f}=2)$ öne çıkan görüşlerdir. Veli görüşleri doğrultusunda sosyal kabul alt temasında; arkadaşlık ilişkilerinde gelişme $(\mathrm{f}=1)$, ilk defa farklı öğrencilerle oturma ( $\mathrm{f}=1$ ) öne çıkan görüşlerdir. Aşağıda takım destekli bireyselleştirme tekniğinin yansımaları teması ve alt temaları ile ilgili veli görüşleri doğrudan alıntılarla verilmiştir. Akademik başarı alt teması ile ilgili veli görüşlerinden doğrudan alıntılar:

“...Oğlum yaptıkları etkinlikleri gösterdi. Bu günkü konuları çok iyi öğrendiğini söyledi. Tüm soruları yapmış, çalışma kağıtlarını gösterdi. Takım yarışması olduğunu söyledi...” (V4)

“...o gün matematik ögretmeni oğluma belge vermiş. Eve geldiğinde hemen gösterdi. Hayatında ilk defa belge ald, çok mutlu oldu, bende oğlumla gurur duydum. Pek alışık olmadığımız şeyler aslında..." (VK1)

Tutum alt teması ile ilgili veli görüşlerinden doğrudan alıntılar:

“...Kart vermişsiniz evde bile taktı... dersi sevdi, öğretmenimiz çok iyi dedi. Mutluydu, onu mutlu görünce bende mutlu oldum...” (V1)

“...matematik dersini sevdiğini söyleyebilirim...” (V2) 
“...Oğlum pek derste neler yaptıklarını anlatmazdı...Ama matematik dersi olan gün heyecanla derste yaptıklarını anlattı... Matematikten daha çok bahsetmeye başladl. Özellikle matematik dersi olduğu gün, etkinlik, yarışma olduğu için çok mutlu oluyor..." (V3)

“...oğlum akşam "ilk dersin olduğu gün babasına yeni ögretmen geldi matematiği çok güzel anlatıyor, matematik aslında çok kolaymış” dedi. Evde sürekli okulda yaptıkları şeyleri anlattı..." (VK3)

Sosyal kabul alt teması ile ilgili veli görüşlerinden doğrudan alıntılar:

"Ŏglum ilk defa başka ögrencilerle oturdu. Sinıfta genelde T ve O...adında ögrencilerle oturuyordu. Bu çocukların dersleri iyi değildi, davranışlarını da beğenmiyordum. Öğretmen değiştireceğim yerini dedi ama değiştirmedi. Başka arkadaşlarla, hatta çalışkan çocuklarla oturmuş. Böyle değişik çocuklarla oturması çok iyi oldu. Çünkü sınıfta bu türlü etkinliklere bizim çocuklar çok tercih edilmiyordu. O yüzden bir veli olarak mutlu oldum." (VK1)

“...ilk defa bazı arkadaşları eve geldi, telefonla görüştüler. Aynı gruptalarmış, yarışma yapıyorlarmış.” (V2)

Takım destekli bireyselleştirme tekniğinin öğrencilere yansımalara temasına yönelik veli görüşleri incelendiğinde akademik başarı boyutunda velisi bulundukları öğrencilerin matematik dersinde konuları daha iyi öğrendiklerini, tutum boyutunda matematik dersine yönelik ilgilerinin arttığını, belge aldığı için mutlu olduğunu, matematik dersini sevdiğini, öğrencilerin motivasyonunun arttı̆̆ını, matematik dersini kolay bulduklarını, tekniğin uygulanmasında kullanılan yaka kartlarını çok sevdiklerini, sosyal kabul boyutunda ise arkadaşlık ilişkilerinin geliştiğini, ilk defa farklı öğrencilerle oturduklarını söylemişlerdir.

Tablo 3. Takım Destekli Bireyselleştirme Tekniğinin Uygulanması Teması ve Alt Temaları ile İlgili Veli Görüşleri

\begin{tabular}{|c|c|c|c|}
\hline 3.Tema & Alt Temalar & Görüşler & Frekans \\
\hline \multirow{5}{*}{ 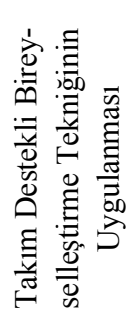 } & \multirow{2}{*}{$\begin{array}{l}\text { Olumlu } \\
\text { yansimalar }\end{array}$} & Uygulama boyunca okula, derse karşı ilgili olması & $1(\mathrm{~V} 3)$ \\
\hline & & Veli katılımını sağlaması & $1(\mathrm{~V} 3)$ \\
\hline & \multirow{3}{*}{$\begin{array}{l}\text { Olumsuz } \\
\text { yansımalar }\end{array}$} & Ödül almadığı için üzülmesi & $1(\mathrm{~V} 1)$ \\
\hline & & Sevmediği öğrencilerle takım olduklarını söylemesi & $1(\mathrm{~V} 2)$ \\
\hline & & $\begin{array}{l}\text { Takımdaki bazı öğrencilerin görevlerini tam yap- } \\
\text { madığını söylemesi }\end{array}$ & $1(\mathrm{~V} 1)$ \\
\hline
\end{tabular}


Tablo 3'te takım destekli bireyselleştirme tekniğinin uygulanması teması ve alt temaları ile ilgili veli görüşleri verilmiştir. Takım destekli bireyselleştirme tekniğinin uygulanması teması ile ilgili veli görüşlerinin olumlu yansımalar ve olumsuz yansımalar olmak üzere olmak üzere iki alt temada toplandığı görülmektedir. Veli görüşleri doğrultusunda olumlu yansımalar alt temasında; uygulama boyunca okula, derse karşı ilgili olması $(\mathrm{f}=1)$, uygulamanın veli katılımını sağlaması ( $\mathrm{f}=1$ ) şeklinde görüş ifade edilmiştir. Olumsuz yansımalar alt temasında; ödül alamadığı için üzülmesi (f=1), sevmediği öğrencilerle takım olduğunu söylemesi $(\mathrm{f}=1)$ takımdaki bazı öğrencilerin görevlerini tam yapmadığını söylemesi (f=1) görüşleri ifade edilmiştir. Aşağıda velilerin takım destekli bireyselleştirme tekniğinin uygulanması teması ve alt temaları ile ilgili veli görüşleri doğrudan alıntılarla verilmiştir. Olumlu yans1malar alt teması ile ilgili veli görüşlerinden doğrudan alıntılar:

“...Matematik dersi olduğu gün eve geldiğinde hep dersten bahsetti...Bu süreçte biz de merak ediyorduk, acaba bu gün neler yaptılar diye. Veli grubumuzda genel olarak çok faydalı olduğuna yönelik paylaşımlar oldu." (V3)

"Okulda yarışma yapmışsınız, kızımın grubundakiler iyi çalışmamış kazanamamışlar. Eve geldiğinde üzgündü, arkadaşlarım yüzünden belge alamadı dedi... Sinıfta bazı ögrenciler almış...” (V1)

Velilerin takım destekli bireyselleştirme tekniğinin uygulanması temasına yönelik görüşleri incelendiğinde olumlu yansımalar boyutunda öğrencilerin uygulama boyunca okula ilgili oldukları, olumsuz yansımalar boyutunda öğrencilerin ödül alamadıkları için üzüldükleri, sevmedikleri öğrencilerle takım oldukları ve takımdaki bazı öğrencilerin görevlerini tam yapmadıkları belirlenmiştir.

\section{Sonuç ve Tartışma}

Velilerin matematik dersinde uygulanan takım destekli bireyselleştirme tekniğine yönelik görüşlerinin üç tema altında toplandığı belirlenmiştir. Takım destekli bireyselleştirme tekniğinin değerlendirilmesi temasına yönelik görüşleri incelendiğinde öğrencilerin derste yapılan etkinlikleri çok sevdikleri, matematik derslerinin güzel geçtiğini gözlemledikleri, öğrencilerin matematik derslerinin eğlenceli geçtiği, güzel takım çalışmaları yaptıklarını ifade ettikleri belirlenmiştir.

Alanyazın incelendiğinde matematik dersinde takım destekli bireyselleştirme tekniği kullanımının öğrenciler üzerindeki etkilerinin veli görüşlerine 
dayalı incelenmesi hakkında yapılan araştırma bulunmamakla birlikte, alanyazında veli görüşlerinin incelendiği bazı araştırma sonuçlarının (Akbaba-Altun, 2009; Ayaydın ve Katılmış, 2017), araştırma bulgularımızı desteklediği söylenebilir. Akbaba-Altun (2009) tarafindan ilköğretim öğrencilerinin akademik başarısızlığına ilişkin veli görüşlerinin incelendiği araştırmada, araştırmaya katılan veliler öğrencilerin başarısızlık nedenleri arasında, derslerin öğrencilerin ilgisini çekmemesi, derslerde grup çalışmalarına yer verilmemesi, öğretmenlerin dersleri monoton işlemesi gibi başarısızlık gerekçeleri sıralamışlardır. Veliler akademik başarısızlığın giderilmesine yönelik öneriler olarak da derslerin eğlenceli etkinlikler şekilde planlanması, küçük grup çalışmalarına yer verilmesi, bilgilerin oyunlaştırılarak verilmesinin etkili olacağını belirtmişlerdir. Araştırmamızda elde edilen veli görüşleri incelendiğinde, takım destekli bireyselleştirme tekniğinin akademik başarısızlığa ilişkin velilerin beklentilerine cevap veren bir öğretim tekniği olduğu söylenebilir. Ayaydın ve Katılmış (2017) tarafından yapılan araştırmaya katılan velilerin çoğunluğu, öğretmenlerin derslerde farklı öğretim yöntemlerine yer vermedikleri, bu yüzden derslerin öğrencilerin ilgisini çekmediğini belirtmişlerdir. Takım destekli bireyselleştirme tekniğinin öğrenci merkezli uygulamalara dayanması ve içeriğinin etkinliklere dayalı olmasının öğrencilerin derse ilgisini artırmada etkili olduğu söylenebilir.

Takım destekli bireyselleştirme tekniğinin öğrencilere yansımalara temasına yönelik görüşlere göre, akademik başarı boyutunda velisi bulundukları öğrencilerin konuları daha iyi öğrendikleri belirlenmiştir. İlgili alanyazını incelendiğinde takım destekli bireyselleştirme tekniğinin uygulanmasına yönelik veli görüşlerinin incelendiği bir araştırma olmamakla birlikte, tekniğin öğrencilerin ders başarılarını olumlu yönde etkilediğine yönelik birçok araştırma yapılmıştır (Aslan, 2016; Erkoç ve Artut, 2016; Gelici, 2011; Gelici ve Bilgin, 2011; Gelici ve Bilgin, 2012; Gülsar, 2014; İflazoğlu, 1999; Koç, 2015; Özdoğan, 2008; Tarım ve Akdeniz, 2008; Yıldırım, 2011). Tekniğin ders başarısını arttırdığına yönelik araştırma bulgularının örtüştüğü, tekniğin matematik öğretiminde ders başarısı sağlamada etkili bir öğrenme tekniği olduğu söylenebilir.

Aile görüşlerinin incelendiği araştırmalarda, ailelerin okuldan akademik başarının sağlanması ve kaliteli öğrenme ortamının sunulması yönünde beklentileri olduğu (Nartgün ve Kaya, 2016), okullardaki yürütülen eğitim- 
öğretim faaliyetlerini yeterli bulmadıkları ve iyi bir eğitim-öğretim ortamı istediklerine ilişkin (Ayaydın ve Katılmış, 2017) sonuçlara ulaşılmıştır. Matematik dersinde takım destekli bireyselleştirme tekniğinin uygulamalarının, velilerin akademik başarı ve eğitim öğretim faaliyetlerinin yeterliliğinin sağlanması, iyi bir eğitim-öğretim ortamı sunulması gibi beklentilerini karşılayan bir öğrenme tekniği olduğu söylenebilir.

Velilerin takım destekli bireyselleştirme tekniğinin öğrencilere yans1malara temasına yönelik görüşlerine göre tutum boyutunda öğrencilerin matematik dersine yönelik ilgilerinin arttığı, belge aldığ için mutlu olduğu, matematik dersini sevdiği, öğrencilerin derse kaşı motivasyonunlarının arttığı, matematik dersini kolay buldukları, tekniğin uygulanmasında kullanılan yaka kartlarını çok sevdikleri belirlenmiştir. Ayaydın ve Katılmış tarafından yapılan araştırmada (2017), veliler tarafindan derslerde farklı etkinliklere yer verilmesinin öğrencilerin motivasyonlarını artırmada etkili olduğu belirlenmiştir. İlköğretim öğrencilerinin akademik başarısızlığına ilişkin veli görüşlerinin incelendiği başka bir araştırmada (Akbaba-Altun, 2009), araştırmaya katılan veliler öğrencilerin başarısızlık nedenleri arasında, derslerin ilgi çekmemesi ve öğrencilerin derslere ilgisizliğini belirtmişlerdir. Veliler, akademik başarısızlığın giderilmesine yönelik öneriler olarak öğrencilerin derse katılım ve ilgilerinin sağlanması, öğretmenin dersi sevdirmesi, öğrencilerin başarılı olabileceklerine inandırılması, öğrencilerin ilgilerini derse çekecek etkinliklerin yapılmasının etkili olacağını belirtmişlerdir. Araştırmamızda elde edilen veli görüşleri incelendiğinde, takım destekli bireyselleştirme tekniğinin tutum boyutundaki bulgularının velilerin beklentilerini karşıladığı, takım destekli bireyselleştirme tekniğinin öğrencilerinin derse ilgilerinin artırılması, öğrencilerin dersi sevmesi, matematik dersinde başarılı olmalarına inanmalarına yönelik bulguların benzer olduğu söylenebilir.

Velilerin takım destekli bireyselleştirme tekniğinin öğrencilere yans1malara temasının sosyal kabul boyutunda ise tekniğin öğrencilerin arkadaşlık ilişkilerinin gelişmesine katkı sağladığı, öğrencilerin ilk defa farklı öğrencilerle oturdukları belirlenmiştir. Ayaydın ve Katılmış tarafından yapılan araştırmada (2017) veliler okullardan öğrencilerin sosyalleşmesine yönelik beklentileri olduğu, Akbaba-Altun (2009) tarafindan yapılan araştırmada ise veliler, öğrencilerin başarısızlıklarının çözümüne yönelik olarak arkadaşlık ilişkilerinin geliştirilmesine vurgu yapmışlardır. Her iki araştırmada belirtilen 
veli beklentileri ile araştırmanın sosyal kabul boyutuna yönelik sonuçların örtüştüğü söylenebilir.

Velilerin takım destekli bireyselleştirme tekniğinin uygulanması temasının olumlu yansımalar boyutunda, öğrencilerin uygulama boyunca okulla ilgili oldukları, olumsuz yansımalar boyutunda ise öğrencilerin ödül alamadıkları için üzüldükleri, sevmedikleri öğrencilerle takım oldukları ve takımdaki bazı öğrencilerin görevlerini tam yapmadıkları belirlenmiştir. Yapılan araştırmalarda aile katılımının öğrencilerinin akademik başarılarını arttırdığı (Hayakawa, Englund, Warner-Richter ve Reynolds, 2013; Topor, Keane, Shelton ve Calkins, 2010) belirlenmiştir. Uygulama boyunca velilerin okulla ilgili olmalarının, tekniğin aile katılımını sağlamada etkili ve destekleyici bir öğretim tekniği olduğu söylenebilir. Velilerin süreç boyunca okulla ilgili olmalarında, öğrencilerin matematik derslerinde yaşadıkları olumlu öğretim sürecini ve yansımalarını aileleri ile paylaşmalarının etkili olduğu söylenebilir.

Yarışmaya dayalı grupla öğretim aktivitelerine katılan ve kaybeden öğrencilerin olumsuz duygular yaşadığı (Lam ve Seaton, 2016), yaşadıkları olumsuz duygular sonucu üzüntü duydukları, öğrenmeye yönelik motivasyonlarının azaldığ 1 , bu durumun sınıftaki öğrenme iklimine ve öğrenciler arası ilişkilere olumsuz etkilerinin olduğu belirlenmiştir (Carson, Bartneck, ve Voges, 2013; Clinkenbeard, 1989; DiMenichi ve Tricomi, 2015; Kristensen, Troeng, Safavi ve Narayanan, 2015; Lam, Yim, Law ve Cheung, 2001; Nelson ve Dawson, 2017; Vockell, 2004). Uygulamada ödül alamayan öğrencilerinde benzer duygular yaşadığı, tekniğin yarışmacı yönü yerine tekniğin de felsefesine uygun olarak bireysel odaklı değerlendirme ile bu durumun aşılabileceği söylenebilir.

Araştırma sonuçlarına göre veliler, çocuklarının sevmedikleri öğrencilerle takım olduklarını ve takımdaki bazı öğrencilerin görevlerini tam yapmadıklarına yönelik görüşlere sahip oldukları belirlenmiştir. İşbirliğine dayalı öğrenme yönteminin uygulandığı bazı araştırmalarda, öğrencilerin sorumluluklarını yerine getirmemeleri, grup içi problemler, grupta yeterli çabayı göstermeyen öğrencilerin de başarıya ortak olması yöntemin uygulanmasına yönelik olumsuzluklar olarak ifade edilmiştir (Açıkgöz, 2007; Demirtaş, 2008; Turaçoğlu, 2011; Ünlü ve Aydıntan, 2011; Yılar ve Şimşek, 2017). Grup çalışmalarında grupların dağılımlarının eşit olmaması, grup ödüllerinde bazı grupların sürekli baskın çıkması, kaybeden grupların öğrenmeye karşı direnç 
oluşturma, derse karşı olumsuz tutum, üzülme ile motivasyon kaybı yaşamaları gibi sonuçlar ortaya koyabilir. Grupların eşit olarak ayarlanması, grup üyelerinin değişiminde denkliğe dikkat edilmesi gerekir. Sınıfta yarışma ve rekabet ortamından çok, öğrenme ürününe dikkat çekilmesi gerekir. Bu noktada öğretmenin öğrencilerin ödülden çok öğrenme ürününe güdülenmelerini sağlaması adına grup çalışmalarını sürekli izlemesi, gruplar arasında dolaşması, kısa açıklamalarla süreci yönetmesi, grup çalışmalarını dinamik tutmak için nitelikli çalışma materyalleri hazırlaması ve öğrencilere çalışmalarında mentörlük yapması uygulamada yaşanabilecek olumsuzlukları azaltmada etkili olabilir.

Araştırma sonuçlarına göre takım destekli bireyselleştirme öğrenme tekniğinin öğrencilerin matematik ders başarılarını artırdığı, tekniğin öğretim uygulamasının eğlenceli ve etkinlik tabanlı olması nedeniyle öğrencilerin derse ilgilerini artırdığı, matematik dersini sevdirdiği ve öğrencilerin derse karş1 olumlu tutum geliştirmelerinde etkili olduğu belirlenmiştir. Uygulama boyunca gerçekleştirilen grup çalışmalarının öğrencilerin arkadaşlık ilişkilerini geliştirdiği, sınıflarında yer alan farklı özelliklere sahip öğrencilere yönelik sosyal kabul sağladığı söylenebilir. Ayrıca hem normal gelişim gösteren öğrencilerin hem de öğrenme güçlüğü olan kaynaştırma öğrencilerinin öğretim uygulamaları boyunca okula ilgilerinin arttı̆̆ 1 ve bu durumun veliler tarafindan da olumlu karşılandı ğ belirlenmiştir. Görevini yerine getirmeyen öğrenciler, ödül alama, sevmediği öğrenciler ile birlikte oturma gibi uygulamaya yansıyan sorunların ise öğretim sürecinin daha fazla zamana yayılması, takımalrın seviyelerinin yakın oluşturulması, öğretim sürecinin daha iyi planlanması ile kısmen azalabileceği söylenebilir.

Araştırma sonuçlarına göre, matematik dersi öğretiminde takım destekli bireyselleştirme tekniği kullanımına yönelik normal gelişim gösteren öğrenciler ile özel öğrenme güçlüğü olan kaynaştırma öğrenci velilerinin görüşlerinin olumlu olduğu, tekniğin öğrenme çıktıları açısından öğrencilerin akademik ve sosyal gelişimlerine katkı sağladığı, tekniğin veli katılımını da olumlu yönde desteklediği belirlenmiştir.

\section{Kaynakça}

Açıkgöz, K. Ü. (2007). Aktif ögrrenme. İzmir: Biliş.

Akbaba-Altun, S. (2009). İlköğretim öğrencilerinin akademik başarısızlıklarına ilişkin veli, öğretmen ve öğrenci görüşlerinin incelenmesi. Ilköğretim Online, $8(2), 567-586$.

Aktan, O. (2018). Kaynaştırma eğitiminde takım destekli bireyselleştirme tekniğinin 
ögrencilerin ders başarısı derse karşı tutum ve sosyal kabul düzeylerine etkisi. Yayımlanmamış doktora tezi, Gazi Üniversitesi Eğitim Bilimleri Enstitüsü.

Aktan, O. ve Budak, Y. (2017). Determination of teachers' opinions on the education of the inclusive students with special learning disability. Journal of Education and Practice, 8(21), 53-65.

Aktaş-Arnas, Y. (2013). Okul öncesi eğitimde aile katılımı. Y. Aktaş Arnas, (Ed.), Aile eğitimi ve okul öncesinde aile katılımı içinde (54-61). Ankara: Vize Yayıncilik.

Allen, K. E. ve Cowdery, G. E. (2015). The exceptional child: Inclusion in early childhood education (8. bask1). Stamford, CT: Cencage Learning.

Amerikan Psikiyatri Birliği. (1994). Mental bozuklukların tanısal ve istatistiksel elkitabı (4. baskı). (E. Köroğlu, Çev.). Ankara: Hekimler Yayın Birliği. (Orijinal çalışma basım tarihi 1994.)

Aral, N. (2011). Okul öncesi ĕgitimde kaynaştırma. İstanbul: Morpa.

Aslan, G. (2016). Küme destekli bireyselleştirme tekniğinin yedinci sınıf ögrencilerin rasyonel sayılar konusundaki başarılarına ve matematiğe yönelik kaygı, tutum ve özyeterlik algılarına etkisi. Yayımlanmamış yüksek lisans tezi, Atatürk Üniversitesi Eğitim Bilimleri Enstitüsü.

Ayaydın, Y. ve Katılmış, A. (2017). Okullardaki eğitim-öğretim faaliyetlerine ilişkin velilerin görüşleri: nitel araştırma. Disiplinlerarası Eğitim Araştırmaları Dergisi, 1(1), 11-28.

Bruffy, W. R. (2012). Authentic tasks: a participatory action research study on a teaching method for the inclusive classroom. Doktora tezi, Northeastern Üniversitesi. http://hdl.handle.net/2047/d20002575 adresinden erişilmiştir.

Bryant, D. P., Smith, D. D. ve Bryant, B. R. (2008). Teaching students with special needs in inclusive classrooms. Boston, MA: Allyn \& Bacon.

Büyüköztürk, Ş. (2017). Sosyal bilimler için veri analizi el kitabı: Ístatistik, araştırma deseni, SPSS uygulamalart ve yorum (22. bask1). Ankara: PegemA.

Büyüköztürk, Ş., Çokluk-Bökeoğlu, Ö. ve Köklü, N. (2008). Sosyal bilimler için istatistik (3. bask1). Ankara: PegemA.

Carson, L., Bartneck, C. ve Voges, K. (2013). Over-competitiveness in academia: a literature review. Disruptive Science and Technology, 1(4), 183-190.

Cavkaytar, A. (2013). Özel eğitime gereksinim duyan çocuklar ve özel eğitim. İ. H. Diken, (Ed.), Özel ĕgitime gereksinimi olan ögrrenciler ve özel ĕgitim içinde (1-28). Ankara: PegemA.

Chinn, S. (2012). Research article beliefs, anxiety, and avoiding failure in mathematics. Hindawi Publishing Corporation Child Development Research, 1(Special Issue), 1-8. doi:10.1155/2012/396071.

Clinkenbeard, P. R. (1989). The motivation to win: Negative aspects of success at competition. Journal for the Education of the Gifted, 12(4), 293-305.

Doi: $10.1177 / 016235328901200405$

Cooper, J. ve Mueck, R. (1990). Collaborative inquiry into the pedegogical use of storytelling and acting. Journal on Excellence in College, 9(3), 65-79.

Cömert, D. ve Güleç, H. (2004). Okul öncesi eğitim kurumlarında aile katılımının önemi: Öğretmen-aile-çocuk ve kurum. Afyon Kocatepe Üniversitesi Sosyal Bilimler Dergisi, 4(1), 131-145. 
Çelebi, C. (2006). Yapılandırmacılık yaklaşımına dayalı işbirlikli öğrenmenin ilköğretim 5. sınıf sosyal bilgiler dersinde ögrenci erişi ve tutumlarına etkisi. Yayımlanmamış yüksek lisans tezi, Selçuk Üniversitesi, Sosyal Bilimler Enstitüsü.

De Boer, A. A., Pijl, S. J. ve Minnaert, A. (2010). Attitudes of parents towards inclusive education: a review of the literature. European Journal of Special Needs Education, 25(2), 165-181.

Demirtaş, F. (2008). İ̧̧birlikli öğrenmede birleştirme I tekniğinin ilköğretim beşinci sınıf ögrencilerinin fen ve teknoloji dersine ilişkin tutumların etkisi. Yayımlanmamış yüksek lisans tezi, Abant İzzet Baysal Üniversitesi Sosyal Bilimler Enstitüsü.

DiMenichi, B. C. ve Tricomi, E. (2015). The power of competition: Effects of social motivation on attention, sustained physical effort, and learning. Frontiers in Psychology, 6(1282), 1-13.

Ellala, Z. ve Alslaq, M. (2017). The impact of using cooperative learning strategy on achievement of students with math learning disabilities. American Journal of Educational Research, 5(6), 612-619.

Doi:10.12691/education-5-6-3

Erkoç, A. ve Artut, P. D. (2016). Küme destekli bireyselleştirme tekniğinin 8. sınıf öğrencilerinin geometri başarılarına ve kalıcılığa etkisi. Hacettepe Üniversitesi Eğitim Fakültesi Dergisi, 31(1), 1-13.

Doi: 10.16986/HUJE.2015013972

Eshun, B. A. (2004). Sex-differences in attitude of students towards mathematics in secondary schools. Mathematics Connection, 4(1), 1-13.

Friend, M. ve Bursuck, W. D. (2014). Including students with special needs: A practical guide for classroom teachers. New Jersey: Pearson.

Fuchs, L. ve Fuchs, D. (1998). General educators' instructional adaptation for students with learning disabilities. Learning Disability Quarterly, 21(1), 2333.

Gelici, Ö. (2011). İşbirlikli öğrenme tekniklerinin ilköğretim 7. sınıf öğrencilerinin matematik dersi cebir ögrenme alanındaki başarl, tutum ve eleştirel düşünme becerilerine etkileri. Yayımlanmamış yüksek lisans tezi, Mustafa Kemal Üniversitesi Sosyal Bilimler Enstitüsü.

Gelici, Ö. ve Bilgin, İ. (2011). İşbirlikli öğrenme tekniklerinin tanıtımı ve öğrenci görüşlerinin incelenmesi. Adlyaman Üniversitesi Fen Bilimleri Dergisi, 1(1), 40-70.

Gelici, Ö. ve Bilgin, İ. (2012). İşbirlikli öğrenme tekniklerinin öğrencilerin cebir öğrenme alanındaki başarı, tutum ve eleştirel düşünme becerilerine etkileri. Abant İzet Baysal Üniversitesi Ë̆itim Fakültesi Dergisi, 12(1), 9-32.

Gillberg, C. ve Soderstrom, H. (2003). Learning disability. Lancet, 362(9386), 11-21. Doi:10.1016/S0140-6736(03)14275-4.

Gülsar, A. (2014). İşbirlikli ögrenmenin matematik başarısına etkisi ve bu yönteme ilişkin ögrenci görüşleri. Yayımlanmamış yüksek lisans tezi, Uludağ Üniversitesi Eğitim Bilimleri Enstitüsü.

Güvenç, H. ve Açıkgöz, K. Ü. (2007). İşbirlikli öğrenme ve kavram haritalarının öğrenme stratejisi kullanımı üzerindeki etkileri. Kuram ve Uygulamada Ĕ̈itim Bilimleri, 7(1), 95-127. 
Haager, D. ve Klingner, J. K. (2005). Differentiating instruction in inclusive classrooms. Columbus, OH: Merril.

Hayakawa, M., Englund, M. M., Warner-Richter, M. N. ve Reynolds, A. J. (2013). The longitudinal process of early parent involvement on student achievement: A path analysis. NHSA Dialog, 16(1), 103-126.

Hirano, K. A. ve Rowe, D. A. (2016). A conceptual model for parent involvement in secondary special education. Journal of Disability Policy Studies, 27(1), 4353.

Doi: $10.1177 / 1044207315583901$

Hossain, A. ve Tarmizi, R. A. (2011). Cognitive and affect outcomes of group learning among secondary learners in Bangladesh. Procedia-Social and Behavioral Sciences, $28,845-850$.

Doi:10.1016/j.sbspro.2011.11.155

İflazoğlu, A. (1999). Küme destekli bireyselleştirme tekniğinin temel eğitim beşinci sını öğrencilerinin matematik başarısı ve matematiğe ilişkin tutumları üzerindeki etkisi. Yayımlanmamış yüksek lisans tezi, Çukurova Üniversitesi Sosyal Bilimler Enstitüsü.

Kançeşme, C. (2015). Özel ögrrenme güçlüğ̈̈ olan öğrencilere sayıların ingilizce yazımının öğretiminde eşzamanlı ipucu ile kapat-kopyala-karşılaştır yöntemlerinin etkililiklerinin karşılaştırılması. Yayımlanmamış yüksek lisans tezi, Abant İzzet Baysal Üniversitesi Eğitim Bilimleri Enstitüsü.

Koç, B. (2015). İşbirlikli öğrenme yönteminin matematik dersindeki erişiye, kalıcılı̆̆a ve sosyal beceriye etkisi. Yayımlanmamış yüksek lisans tezi, Adnan Menderes Üniversitesi Sosyal Bilimler Enstitüsü.

Köroğlu, E. (2013). DSM 5 tanı ölçütleri başvuru el kitabı. Ankara: HYB Yayınları.

Kratochwill, T. R., McDonald, L., Levin, J. R., Scalia, P. A. ve Coover, G. (2009). Families and schools together: An experimental study of multi-family support groups of children at risk. Journal of School Psychology, 47(2), 245-265.

Doi: 10.1016/j.jsp.2009.03.001

Kristensen, F., Troeng, O., Safavi, M. ve Narayanan, P. (2015). Competition in higher education - good or bad? Lund University. http://portal.research.lu.se/portal/files/5680982/8519800.pdf.

Kusumayanti, F. (2014). The implementation of cooperative learning model type team assisted individualization (TAI) to improve student's accounting learning activity. Yayımlanmamış lisans tezi. http://eprints.uny.ac.id/15567/1/UNDERGRADUATE\%20THESIS.pdf

Lam, S., Yim, P., Law, J. ve Cheung, R. (2001, Ağustos). The effects of classroom competition on achievement motivation. Amerikan Psikoloji Birliği 109. Y1llı Konferansı'nda sunulan bildiri, San Francisco.

Lam, V. L. ve Seaton, J. (2016). Ingroup/outgroup attitudes and group evaluations: The role of competition in British classroom settings. Child Development Research, 1(1),1-10.

Doi: $10.1155 / 2016 / 8649132$

Lewis, R. B. ve Doorlag, D. H. (2011). Teaching students with special needs in general education classrooms (8. bask1). Upper Saddle River, NJ: Pearson.

Madden, N. A. ve Slavin, R. E. (1983). Effects of cooperative learning on the social acceptance of mainstreamed academically handicapped students. Journal of 
Special Education, 17(2), 171-182.

MEB (2014). Özel ĕgitim hizmetleri yönetmeliği. Ankara: MEB Yayınları.

MEB (2017). Kaynaştırma/bütünleştirme yoluyla eğitim uygulamaları genelgesi $(2017 / 28)$.

https://orgm.meb.gov.tr/meb_iys_dosyalar/2017_09/21112929_kaynastirma_genelge.pdf

MEB (2019). Milli Ĕ̌gitim Bakanlı̆̆l strateji geliştirme başkanlı̆̆l istatistikleri örgün eğitim. https://sgb.meb.gov.tr

Melekoğlu, M. (2017). Özel öğrenme güçlüğüne giriş. M. A. Melekoğlu ve O. Çak1roğlu, (Ed.), Özel ögrenme güçlüğ̈̈ olan çocuklar içinde (15-44). Ankara: Vize.

Merriam, S. B. (2013). Nitel araştırma desen ve uygulama için bir rehber. (S. Turan, Çev.). Ankara: Nobel. (Orijinal çalışma basım tarihi 2009.)

Miksic, M. Y. (2015). Parent involvement: theory, practice, and head start. CUNY Institute for Education Policy, 22(4), 1-11.

Miles, M. B. ve Huberman, A. M. (2015). Genişletilmiş bir kaynak kitap: Nitel veri analizi. (S. Akbaba-Altun ve A. Ersoy, Çev. Ed.). Ankara: Pegem. (Orijinal çalışma basım tarihi 2013.)

Nartgün, Ş. ve Kaya, A. (2016). Özel okul velilerinin beklentileri doğrultusunda okul imajı oluşturma. Eğitim ve Öğretim Araştırmaları Dergisi, 5(2), 153-167.

Nelson, R. ve Dawson, P. (2017). Competition, education and assessment: Connecting history with recent scholarship. Assessment \& Evaluation in Higher Education, 42(2), 304-315.

Doi: $10.1080 / 02602938.2015 .1105932$

Osborne, A. G. ve Dimattia, P. (1994). The least restrictive envinronment mandante: Legal implications. Exceptional Children, 61(1), 6-14.

Doi: $10.1177 / 001440299406100102$

Özdoğan, E. (2008). İşbirlikli ögrrenme yönteminin ilköğretim 4. sinıf matematik öğretiminde ögrrenci tutum ve başarısına etkisi: Bilgisayar destekli işbirlikli öğrenme ve küme destekli bireyselleştirme tekniği. Yayımlanmamış yüksek lisans tezi, Ege Üniversitesi Sosyal Bilimler Enstitüsü.

Parker, B. (2006). Instructional adaptations for students with learning disabilities: an action research project. Intervention in School and Clinic, 42(1), 56-58.

Pijl, S. J., Meijer, C. J. W. ve Hegarty, S. (1997). Inclusive education: a global agenda. London: Routledge.

Rafferty, Y., Boettcher, C. ve Griffin, K. W. (2001). Benefits and risks of reverse inclusion for preschoolers with and without disabilities: parents' perspectives. Journal of Early Intervention, 24(4), 266-286.

Doi: $10.1177 / 105381510502700305$

Salend, S. J. (2008). Creating inclusive classrooms: Effective and reflective practices $\left(6^{\text {th }}\right.$ ed). Columbus, OH: Merril/Prentice Hall.

Slavin, R. E. (1985). An introduction to cooperative learning research. R. E. Slavin, S. Sharan, S. Kagan, R. Hertz-Lazarowitz, C. Webb ve R. Schmuck, (Ed.), Learning to cooperate, cooperating to learn içinde (5-15). New York: Plenum.

Slavin, R. E., Madden, N. A. ve Leavey, M. (1984). Effects of team assisted individualization on the mathematics achievement of academically 
handicapped and nonhandicapped students. Journal of Educational Psychology, 76(5), 813-819.

Doi: 10.1037/0022-0663.76.5.813

Sucuoğlu, B. ve Kargın T. (2014). Illköğretimde kaynaştırma uygulamaları. Ankara: Kök.

Şimşek, Ü., Doymuş, K. ve Bayrakçeken, S. (2004, Temmuz). Lise düzeyinde öğrenim gören ögrrencilere grupla ögrenme metodunun kazandırdı̆̆ı bilgi ve beceriler. XIII. Ulusal Eğitim Bilimleri Kurultayı'nda sunulmuş bildiri, İnönü Üniversitesi, Malatya.

Tarım, K. ve Akdeniz, F. (2008). The effects of cooperative learning on Turkish elementary students' mathematics achievement and attitude towards mathematics using Tai and Stad Methods. Educational Studies in Mathematics, 67(1), 7791.

Tilaar, A. L. F. (2014). Effect of cooperative learning model type of team assisted individualization (TAI) and the performance assessment of learning achievement to linear program course. International Journal of Science and Engineering Investigations, 3(24), 25-29.

Topor, D. R., Keane, S. P., Shelton, T. L. ve Calkins, S. D. (2010). Parental involvement and student academic performance: A multiple mediational analysis. Journal of Prevention \& Intervention in the Community, 38(3), 183-197.

Doi: 10.1080/10852352.2010.486297

Turaçoğlu, İ. (2011). Öğretmen adaylarının grup araştırması tekniğine yönelik öz değerlendirmeleri. Buca Ĕgitim Fakültesi Dergisi, 31, 39-47.

Ural, A. (2007). İşbirlikli öğrenmenin matematikteki akademik başarıya, kalıcılı̆̆a, matematik özyeterlik algısına ve matematiğe karşı tutuma etkisi. Yayımlanmamış doktora tezi, Gazi Üniversitesi Eğitim Bilimleri Enstitüsü.

Ünlü., M. ve Aydıntan, S. (2011). İşbirlikli öğrenme yönteminin 8. sınıföğrencilerinin matematik dersi "permütasyon ve olasılık" konusunda akademik başarı ve kalıc1lık düzeylerine etkisi. Ahi Evran Üniversitesi Eğitim Fakültesi Dergisi. $12(3), 1-16$.

Waanders, C., Mendez, J. L. ve Downer, J. T. (2007). Parent characteristics, economic stress, and neighborhood context as predictors of parent involvement in preschool children's education. Journal of School Psychology, 45(6), 619-636.

Doi: $10.1016 /$ j.jsp.2007.07.003

Yeşilyurt, E. (2010). Öğretmen adaylarının niteliklerinin işbirliğine dayalı öğrenme yöntemine uygunluğunun değerlendirilmesi. Dicle Üniversitesi Ziya Gökalp Eğitim Fakültesi Dergisi, 14, 25-37.

https://dergipark.org.tr/tr/pub/zgefd/issue/47952/606706

Yeşilyurt, E. (2019). İşbirliğine dayalı öğrenme yöntemi: Tüm teknikleri kapsayıcı bir derleme çalışması. Turkish Studies Educational Sciences, 14(4), 1941-1970. Doi: 10.29228/TurkishStudies.23449

Y1lar, M. B. ve Şimşek, U. (2017). Sosyal bilgiler dersinde işbirlikli öğrenme yöntemlerinin başarı ve kalıcılığa etkileri. Kastamonu Eğitim Dergisi, 25(2), 1-15.

Yıldırım, A. ve Şimşek, H. (2013). Sosyal bilimlerde nitel araştırma yöntemleri. Ankara: Seçkin.

Yıldırım, Z. (2011). Kubaşık öğrenme yönteminin küme destekli bireyselleştirme tek- 
niğinin 6. sınıf öğrencilerinin matematik dersindeki başarılarına ve tutumlarına etkisi. Yayımlanmamış yüksek lisans tezi, Atatürk Üniversitesi Eğitim Bilimleri Enstitüsü.

Yin, R. K. (2011). Qualitative research from start to finish. New York: The Guilford Press.

Yin, R. K. (2012). Case study methods. H. Cooper, P. M. Camic, D. L. Long, A. T. Panter, D. Rindskopf ve K. J. Sher, (Ed.), APA handbook of research methods in psychology, Vol. 2. Research designs: Quantitative, qualitative, neuropsychological, and biological içinde (141-155). Washington DC: American Psychological Association.

Doi:10.1037/13620-009 